\title{
Aplikasi ayat-ayat bisnis dalam al-Qur'an pada pesantren enterpreneur: studi kasus di Pondok Pesantren Sidogiri Pasuruan
}

\author{
Moh. Toriquddin \\ Fakultas Syariab UIN Maulana Malik Ibrabim Malang \\ E-mail:bm.toriquddin@gmail.com \\ DOI: 10.18326/ijtihad.v15i2.177-198
}

\begin{abstract}
This research discusses the application of Quran verses of business in Sidogiri boarding school, Pasuruan. It is aimed at explaining how verses of business in the Holy Quran are applied in the business of Sidogiri boarding school, Pasuruan. Qualitative research is applied. Data are analyzed through thematic interpretation. The study shows that the application of verses of business in the Quran is a form of worship. Professionalism and ethic of business in BMT UGT Sidogiri has already been well practiced as a form of worship which employs legal contract in Islamic law; application of principle of honesty (shiddiq), communicativeness (tablig), trustworthiness (amanab), and professional (fatanah) in running business as the manifestation of worship in Allah. Professionalism in business can be known from the use of justice principle; the absence of additional money from customer, the guarantee of keeping customer's privacy, and the modern system of money management which uses e-banking system. Ethic of business is such particular soft rejection towards customers and good service.
\end{abstract}

Penelitian ini mengangkat tentang aplikasi ayat-ayat bisnis dalam al-Qur'an pada pesantren Sidogiri Pasuruan. Tujuan dari penelitian ini adalah untuk mendeskripsikan bagaimana ayat-ayat bisnis dalam alQur'an diaplikasikan pada usaha bisnis di pesantren Sidogiri Pasuruan. Penelitian ini adalah penelitian kualitatif dengan pendekatan tafsir tematik. Hasil penelitian menunjukkan bahwa bisnis sebagai ibadah ditandai dengan akad syar'i, aktifitas bisnis tidak melupakan untuk beribadah kepada Allah dan penggunaan prinsip kejujuran (shiddiq), komunikatif (tabligh), amanah (dapat dipercaya), fathonah (profesional) dalam menjalankan bisnis. Bisnis profesional ditandai dengan penerapan prinsip keadilan dengan cara tidak mengenakan uang tambahan bagi nasabah dan menjaga kerahasiaan identitas nasabah serta sistem pencatatan keuangan modern dengan system e-banking. Bisnis beretika ditandai dengan penolakan terhadap nasabah dengan lemah lembut dan melayaninya dengan sopan santun.

Keywords: Business; Entrepreneurship; Boarding school; Sidogiri 


\section{Pendahuluan}

Sejak masa penjajahan Belanda, pesantren memainkan peranan yang terbatas. Pesantren hanya mengkaji ilmu-ilmu keislaman klasik dengan nuansa kesederhanaan, bahkan sering diidentikkan dengan 'pedesaan'(Qamar, 2007: 23). Peran pesantren sejak dulu memang tidak pernah lepas dengan peran edukatif yang murni mengajarkan ilmu-ilmu keislaman (SM, 2002: 53). Pondok Pesantren umumnya dikenal sebagai perguruan swasta yang berkemampuan tinggi dalam berswakarsa dan berswakarya dalam menyelenggarakan pendidikan (Usa dan Wijdan, 1997: 12).

Di era modern Pesantren selain dituntut untuk memperkuat penanaman nilai-nilai spiritual ('ubüdiyyah) kepada para santri, juga dituntut untuk memperkaya penanaman aspek tanggung jawab, rasionalitas dan pemecahan masalah (Mas'ud, 2000: 141). Selain itu, pesantren juga selalu dituntut untuk melakukan adjustment and readjustment (Azra, 1999: 108), mulai dari melakukan diversifikasi program dengan membuat yayasan, memasukkan sistem sekolah, kontekstualisasi kitab kuning, memodernisasi manajemen pengelolaan, dengan memasukkan fungsi sosial ekonomi ke dalam program pesantren dan lain-lain. Sekarang ini Pesantren tidak hanya membekali para santri dengan ilmu-ilmu keislaman tetapi telah memberikan ketrampilan yang bersifat aplikatif dan siap kerja (Qamar, 2007: 79).

Tuntutan dan kebutuhan masyarakat juga berdampak terhadap eksistensi pesantren saat ini. Persepsi masyarakat yang masih kuat di seputar 'dunia kerja' menjadikan keberadaan suatu pesantren terancam. Persoalan seperti ini masih membayangi pesantren, khususnya yang masih mempertahankan ciri khas "kesalafiyahan-nya" (Raharjo, 1988: 42).

Peneliti sengaja menentukan lokus penelitian pada pesantren Sidogiri Pasuruan, karena pesantren tersebut dianggap mewakili model pesantren intrepreneur di Jawa Timur. Dengan berbagai alasan sebagai berikut: Pertama, pondok pesantren Sidogiri merupakan salah satu pesantren tertua di Jawa Timur yang telah berusia ratusan tahun yaitu berdiri sejak tahun 1745 M. Kedua, Usaha pesantren berupa koperasi pesantren di pondok pesantren Sidogiri merupakan usaha pesantren paling awal di Indonesia yang didirikan sejak 1961 dan tetap eksis dan berkembang sampai sekarang. Sehingga mendapat predikat "Pesantren Wirausaha Pertama” versi majalah Republika, 1. November 2002. Ketiga, dari cikal bakal koperasi pesantren lalu lahirlah BMT yang dari segi modal, asset dan omsetnya dalam kurun waktu 
tujuh tahun sejak berdiri tahun 1997-2004 telah mencapai 42 miliar, dan nasabah yang tidak kurang dari 12 ribu orang dengan unit pelayanan 12 unit yang tersebar di berbagai wilayah Kecamatan di Kabupaten Pasuruan. Selanjutnya dari BMT itulah didirikan Koperasi Usaha Gabungan Terpadu (UGT) Sidogiri pada tahun 2002 yang kini telah memiliki 9 unit pelayanan yang tersebar di 9 kabupaten/kota di Jawa Timur (Bakhri, 2004: 13). Keempat, Sidogiri adalah pesantren salafiyah yang telah sukses membangun kemandirian ekonomi dengan ekonomi syari'ahnya di lingkungan tradisional.

Berdasarkan latar belakang di atas maka, dapat dirumuskan rumusan masalah sebagai berikut: Pertama, Bagaimana aplikasi ayat-ayat bisnis dalam al-Qur'an di pesantren intrepreneur Sidogiri Pasuruan? Kedua, Motif apa yang melatar belakangi berdirinya badan usaha di pesantren intrepreneur Sidogiri Pasuruan? Penelitian ini bertujuan memahami aplikasi ayat-ayat bisnis dalam al-Qur'an pada pesantren intrepreneur, mendeskripsikan model pesantren intrepreanur, mengetahui tujuan pendirian koperasi BMT UGT Sidogiri.

Hasil dari studi ini diharapkan bermanfaat untuk mengembangkan kajian-kajian tentang pesantren intrepreneur di Indonesia. Juga bisa dimanfaatkan sebagai pertimbangan-bagi studi selanjutnya. Dan bisa bermanfaat bagi masyarakat luas dalam menggambarkan model pesantren intrepreneur yang pada gilirannya memberikan alternative pendidikan dua dimensi (dimensi agama dan ekonomi), baik bagi calon wali santri pencari institusi pendidikan yang ideal maupun bagi pengelola pesantren yang mencari format pesantren ideal. Penelitian ini secara praktis diharapkan berguna bagi para akademisi yang mempunyai concern dalam kajian tafsir dan pesantren di Indonesia.

\section{Metode penelitian}

Jenis penelitian ini adalah termasuk penelitian kualitatif, karena sifat data yang akan dikumpulkan bercorak kualitatif (Suprayogo dan Tabroni, 2001: 9). Oleh karena itu data penelitian bersifat naturalis dengan memakai logika induktif dan pelaporannya bersifat deskriptif (Nawawi, 2007: 67).

Studi lapangan dilakukan dengan memilih pesantren Sidogiri Pasuruan. Pesantren ini dipilih karena memang sesuai dengan maksud penelitian yaitu untuk meneliti pesantren interpreanur. Dengan metote field research, peneliti terjun langsung menggali data di lapangan 
dengan cara wawancara dan melakukan deskripsi di lapangan untuk mempelajari masalahmasalah dalam koperasi BMT UGT Sidogiri Pasuruan (Robert Bogdan \& Stevan J Taylor, 1975: 33). Wawancara kepada Pengurus koperasi UGT Sidogiri Pasuruan, para karyawan, serta pihak-pihak lain yang terkait, dimaksudkan untuk mendengar keterangan dari mereka dengan fakta-fakta, kejadian-kejadian yang mereka alami dan mereka ketahui (L. Adam, 1952: 5).

Sedangkan pendekatan yang digunakan adalah pendekatan tafsir tematik. Tafsir tematik dianggap tepat untuk dijadikan pisau analisis karena hakikat yang ingin diketahui dalam penelitian ini adalah bagaimana aplikasi ayat-ayat bisnis dilakukan pada pesantren enterpreanur Sidogiri pasuruan. Dengan menggunakan teori tafsir tematik ini, diharapkan bisa membedah praktek aplikasi ayat-ayat bisnis dalam al-Qur'an pada pesantren interpreanur Sidogiri Pasuruan.

\section{Sejarah berdirinya pesantren Sidogiri}

Dalam surat yang ditandatangani oleh al-marhum KA.Sa'doellah Nawawie tertulis, bahwa tahun 1971 merupakan hari ulang tahun PPS yang ke 226, berarti Pondok Pesantren Sidogiri berdiri pada tahun 1745. Dan surat inilah yang dibuat standart peringatan hari jadi/ulang tahun Pondok Pesantren Sidogiri. Tahun 2003 adalah hari jadi PPS yang ke 258.

Pada tanggal 14 Shafar 1357 H atau 15 April 1938, KH. Abd. Djalil, pengasuh Pondok Pesantren Sidogiri saat itu, mendirikan madrasah yang diberi nama Madrasah Miftahul Ulum. Setelah KH.Abd Djalil wafat pada tahun 1947, Pondok Pesantren Sidogiri diasuh oleh KH. Kholil Nawawie. Pada saat itulah, dibentuk suatu wadah permusyawaratan yang diberi nama Pancawarga. Anggotanya adalah lima orang putera KH.Nawawie bin Noer Hasan, yaitu; 1) KH.Noer Hasan (wafat 1967), 2) KH.Kholil (wafat 1978), 3) KH.Siradjul-Millah Waddin (wafat 1988), 4) KA.Sa'doellah (wafat 1972) dan 5) KH. Hasani (wafat 2001). Di dalam statement-nya, kelima putera KH. Nawawie ini merasa berkewajiban untuk melestarikan keberadaan Pondok Pesantren Sidogiri dan merasa bertanggung-jawab untuk mempertahankan asas dan ideologi Pondok Pesantren Sidogiri.

Setelah sebagian besar anggota Pancawarga sudah wafat yakni setelah wafatnya tiga dari anggota Pancawarga, maka KH.Siradjul-Millah Waddin mempunyai gagasan untuk 
membentuk wadah baru. Maka dibentuklah organisasi pengganti yang diberi nama Majelis Keluarga dengan anggota terdiri dari cucu-cucu laki-laki dari KH.Nawawie bin Noer Hasan. Majelis Keluarga saat ini adalah :KH.Abd.'Alim Abd.Djalil : Rois (Pengasuh PP. Sidogiri) KH.Nawawi Abd.Djalil : Katib, sedangkan para anggotanya adalah sebagai berikut: KH.Fuad Noer Hasan, K.Abdullah Syaukat Sirodj, KH.Abd Karim Thoyyib, Mas D.Nawawy Sa'doellah, Mas H.Bahruddin Thoyyib. Saat ini Pondok Pesantren Sidogiri diasuh oleh KH. Abd. Alim bin Abdul Djalil, generasi ke delapan dari Mbah Sayyid dengan sekitar 5000 santri putra dan 3000 santri putri (http://santribawean.blogspot.com/2009/07/sejarahsingkat-ponpes-sidogiri.html).

\section{Sejarah berdirinya UGT Sidogiri}

Koperasi BMT Usaha Gabungan Terpadu Sidogiri disingkat "BMT UGT Sidogiri” mulai beroperasi pada tanggal 5 Rabiul Awal 1421 H atau 6 Juni 2000 M. di Surabaya dan kemudian mendapatkan badan Hukum Koperasi dari Kanwil Dinas Koperasi PK dan M Propinsi Jawa Timur dengan SK Nomor: 09/BH/KWK.13/VII/2000 tertanggal 22 Juli 2000.

BMT UGT Sidogiri didirikan oleh beberapa orang yang berada dalam satu kegiatan Urusan Guru Tugas Pondok Pesantren Sidogiri (Urusan GT PPS) yang di dalamnya terdapat orang-orang yang berprofesi sebagai guru dan pimpinan madrasah, alumni Pondok Pesantren Sidogiri Pasuruan dan para simpatisan yang menyebar di wilayah Jawa Timur.

Dalam setiap tahun BMT UGT Sidogiri membuka beberapa unit pelayanan anggota di kabupaten/kota yang dinilai potensial. Saat ini BMT UGT Sidogiri telah berusia 13 tahun dan sudah memiliki 230 Unit Layanan Baitul Maal wat Tamwil/Jasa Keuangan Syariah dan 1 Unit Pelayanan Transfer.

Pengurus terus berusaha melakukan perbaikan dan pengembangan secara berkesinambungan pada semua bidang baik organisasi maupun usaha. Untuk menunjang hal tersebut maka anggota koperasi dan penerima amanat perlu memiliki karakter STAF, yaitu Shiddiq (jujur), Tabligh (transparan), Amanah (dapat dipercaya) dan Fathanah (profesional) (http://bmtugtsidogiri.co.id/tentang-kami-6.html). 


\section{Aplikasi ayat-ayat bisnis pada BMT UGT Sidogiri}

\section{Bisnis sebagai ibadah}

Data yang diperoleh dari lapangan menunjukkan bahwa semua akad yang digunakan di BMT UGT Sidogiri adalah akad syar'i hal ini sebagaimana dikatakan oleh ustadz Baihaqi sebagai berikut:

Semuanya menggunakan akad yang syar'i, seperti mudlarabah, musyarakah, ijarah, rahn, murabahah, kafalah bil ujrah (Baihaqi, Wawancara: 2015). Sedangkan untuk produk simpanan menggunakan akad mudlarabah musytarakah ( Brosur Produk Simpanan Koperasi Simpan Pinjam Syariah BMT UGT Sidogiri).

Penggunaan akad syar'i di BMT UGT Sidogiri telah sejalan dengan konsep bisnis dalam al-Qur'an, yang mana bisnis dipandang sebagai aktifitas ibadah jika memenuhi tiga unsur yaitu bisnis harus dengan cara halal, tidak melupakan Allah dan bertujuan untuk ibadah sebagaimana telah dijelaskan sebelumnya. Untuk lebih jelasnya berikut analisis aplikasi bisnis di BMT UGT Sidogiri ditinjau dengan teori bisnis perspektif al-Qur'an melaui tiga unsur sebagai berikut: Pertama dengan menggunakan teori induksi dari ayat-ayat bisnis dalam alQur'an yang mengindikasikan bahwa dalam mencari rezeki harus dengan cara yang halal dan baik, bersungguh-sungguh seperti dalam surat al-Taubah/9:105, al-Zumar/39:39, alBaqarah/2: 172:

Dan Katakanlah: "Bekerjalah kamu, Maka Allah dan rasul-Nya serta orang-orang mukmin akan melihat pekerjaanmu itu, dan kamu akan dikembalikan kepada (Allah) yang mengetahui akan yang ghaib dan yang nyata, lalu diberitakan-Nya kepada kamu apa yang Telah kamu kerjakan.Katakanlah: "Hai kaumku, Bekerjalah sesuai dengan keadaanmu, Sesungguhnya Aku akan bekerja (pula), Maka kelak kamu akan mengetahui. Hai orangorang yang beriman, makanlah di antara rezki yang baik-baik yang Kami berikan kepadamu dan bersyukurlah kepada Allah, jika benar-benar kepada-Nya kamu menyembah.

Al-Thabari dalam menafsirkan ayat ini adalah makanlah dari rizki yang halal yang kami halalkan kepada kalian, maka apa yang kami halalkan adalah baik untuk kalian dari pada apa yang kalian haramkan sedangkan kami tidak mengharamkan kepada kalian dari makanan dan minuman. Dan bersyukurlah kepada Allah serta memujilah kepada-Nya terhadap nikmatnikmat yang baik yang telah diberikan kepada kalian jika kalian menyembah kepada-Nya 


\section{Aplikasi ayat-ayat bisnis dalam al-Qur'an...(Moh. Toriquddin )}

(Al-Thabari, 2008: 316). Mencari harta yang halal dan bersungguh-sungguh banyak diterangkan dalam hadits nabi antara lain:

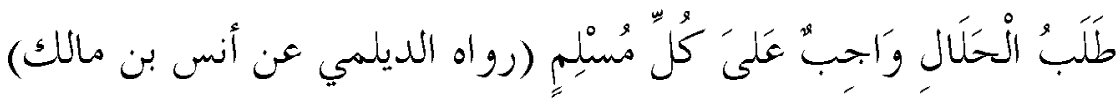

Mencari rezeki halal, merupakan kewajiban setiap muslim. (Riwayat al-Dailami dari Anas bin Malik) (Al-Suyuti, 2000: 54).

Dari beberapa argument di atas bisa dipahami bahwa mencari harta perspektif al-Qur'an harus dengan cara yang halal dan baik, dan di BMT UGT Sidogiri semua akadnya telah menggunakan akad yang syar'i, yaitu akad yang sudah diatur dalam fiqh muamalah seperti akad mudlarabah, musyarakah, ijarah, rahn, murabahah, kafalah bil ujrah. Sedangkan untuk produk simpanan menggunakan akad mudlarabah musytarakah. Dari induksi ayat-ayat dan hadits di atas menghasilkan hukum praktek akad di BMT UGT Sidogiri adalah akad yang sah dan halal serta sesuai dengan al-Qur'an dan Sunnah Rasulullah SAW.

Kedua, dari hasil wawancara ditemukan bahwa aktifitas di koperesi BMT UGT Sidogiri sarat dengan nilai religious atau dengan kata lain dalam berbisnis mereka tidak melupakan Allah hal ini tampak dari wawancara langsung dengan ustadz Ismail berikut:

Waktu Shalat adalah jam istirahat dan semua karyawan melakukan shalat jamaah di mushalla lantai 3. Jadi jelasnya begini, jam kantor mulai jam 08.00 lalu jam 11.30-12.30 jam istirahat mereka menggunakan untuk sholat dan makan, lalu sebelum pulang mereka sholat asar dan jam pulang adalah jam 15.30. hari sabtu jam kantor sampai dengan jam 14.00 dan hari minggu sampai dengan jam 12.00 (Ismail, Wawancara; 2015). Bahkan dalam buku Sukses Koperasi Syari'ah dijelaskan; sebelum memulai kerja pengurus dan karyawan Koperasi BMT UGT Sidogiri melaksanakan shalat dluha berjamaah, siang hari ketika adzan dhuhur berkumandang mereka menghentikan seluruh aktivitas kerja untuk melaksanakan shalat dhuhur berjamaah. Dan sore hari sebelum pulang mereka terlebih dahulu menunaikan shalat ashar berjamaah (Bakhri, 2015: 109).

Fenomena di atas dianalisis menggunakan teori induksi dari ayat-ayat bisnis di dalam alQur'an yang mengindikasikan bahwa dalam bekerja tidak boleh melupakan Allah sebagai mana dalam surat Al-Nur (24):37 berikut:

Laki-laki yang tidak dilalaikan oleh perniagaan dan tidak (pula) oleh jual beli dari mengingati Allah, dan (dari) mendirikan sembahyang, dan (dari) membayarkan zakat. mereka takut kepada suatu hari yang (di hari itu) hati dan penglihatan menjadi goncang. 
Dalam tafsir Mafatih al-Ghaib disebutkan bahwa Salim melihat sekelompok pedagang pasar yang meninggalkan dagangannya dan pergi untuk shalat, mereka adalah kelompok orang yang Allah telah menurunkan ayat: la tulhibim tijaratun. Kemudian Allah menyebutkan kata: al-baiy' (menjual) karena ia lebih melalaikan dibanding dengan membeli karena menjual lebih meyakinkan untuk mendatangkan keuntungan (Al-Razi, 2001: 344).

Sedangkan Ibnu Hayyan menyebutkan bahwa orang-orang yang mensucikan Allah adalah orang-orang yang selalu memperhatikan perintah Allah dan mencari ridlanya sehingga mereka tidak disibukkan selain berdzikir kepada Allah dan menjalankan kewajibannya. Kata tijarah adalah menyebutkan kata umum sedangkan yang dituju adalah kata khusus, maka yang dimaksud dengan perdagangan adalah membeli untuk dijual kembali (Ibnu Hayyan, 2007: 318)

Secara umum al-Qur'an mengingatkan orang-orang yang beriman agar tidak lalai berdzikir kepada Allah dikarenakan kesibukannya terhadap harta, anak, karena sesungguhnya yang demikian adalah termasuk orang-orang yang merugi sebagaimana surat al-Munafiqun ayat: 9:

Hai orang-orang beriman, janganlah hartamu dan anak-anakmu melalaikan kamu dari mengingat Allah. Barangsiapa yang berbuat demikian Maka mereka Itulah orang-orang yang merugi.

Dengan demikian maka apa yang dilakukan oleh para pengurus dan karyawan BMT UGT Sidogiri sudah sesuai dengan pesan-pesan al-Qur'an dengan mempraktekkan ayatayat yang menegaskan agar dalam berbisnis tidak melupakan Allah tetapi justru aktifitas bisnis dijadikan sebagai sarana untuk beribadah kepada Allah swt. Hal ini dibuktikan dengan selalu shalat dhuha berjamaah sebelum memulai aktifitas pekerjaan dan meninggalkan pekerjaan ketika datang adzan dhuhur dan asar berkumandang.

Ketiga, di koperasi BMT UGT Sidogiri dalam melayani nasabah menggunakan prinsip kejujuran (shiddiq), komunikatif (tabligh), amanah (dapat dipercaya), fathonah (profesional). Dengan kata lain mereka menjalankan bisnis sebagai manifestasi ibadah kepada Allah, karena keempat sifat tersebut adalah sifat yang dimiliki oleh Rasulullah saw, dan menerapkan sifatsifat Rasulullah dalam kehidupan berarti taat kepada Rasulullah yang berarti juga taat kepada Allah swt sebagaimana hasil penelusuran di lapangan sebagai berikut: 
Kita terapkan prinsip STAF yaitu singkatan dari shiddiq (jujur) masing-masing pengelolanya adalah orang yang jujur, tabligh(komunikasi yang baik) salah satunya komunikasi melalui website, amanah (dapat dipercaya), dan fathonah (professional) yaitu professional dalam mengelola usaha serta kerja keras, kerja cerdas, kerja tuntas dan kerja ikhlas(Bakhri, 2015: 57).

Data di atas dianalisis menggunakan teori induksi dari ayat-ayat bisnis di dalam al-Qur'an yang mengindikasikan bahwa bekerja memiliki nilai ibadah, karena manusia diciptakan olehNya hanya bertujuan menjadikan segala aktivitasnya berujung pada ibadah kepada-Nya seperti dalam surat al-Dzariyat 51:56 berikut:

Dan Aku tidak menciptakan jin dan manusia melainkan supaya mereka mengabdi kepada$\mathrm{Ku}$.

Maksud dari ayat di atas bahwa segala aktivitas dalam kehidupan berakhir pada ibadah kepada Allah SWT. Huruf Tam yang dibaca li pada kata li ya'budūn mengandung arti akibat, dampak, atau kesudahan, bukan dalam arti "agar". Jika demikian halnya maka kerja harus disertai dengan keikhlasan, dan ini menjadikan pelakunya tidak semata-mata mengandalkan imbalan di sini dan sekarang (duniawi), tetapi pandangan dan visinya harus melampaui batasbatas kekinian dan kedisinian, yaitu kekal di akhirat (Shihab, 2002: 223).

Dalam rangka tujuan ibadah dalam bekerja ini maka cara-cara dalam mencari harta juga harus baik sebagaimana hadits rasulullah saw. sebagai berikut:

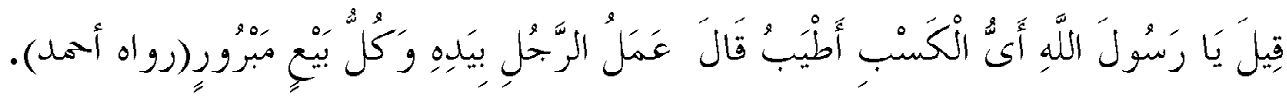

Dikatakan wahai Rasulullah profesi apa yang paling baik? Rasulullah menjawab: usaha seseorang dengan tangannya sendiri dan setiap jual beli yang baik (Ibn Hanbal, 1995: 217)

Bahkan Nabi menjelaskan bahwa jual beli yang baik adalah jual beli yang dilandasi kejujuran, tidak ada kecurangan, tidak ada unsur penipuan dan pengkhianatan sebagai mana hadits berikut ini:

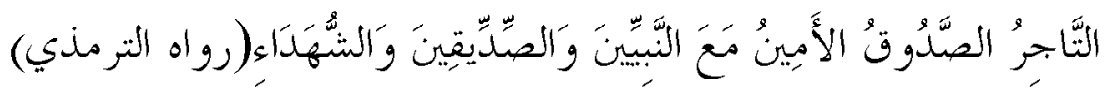

Pedagang yang jujur dan terpercaya sejajar (tempatnya di surga) dengan para Nabi, Shiddiqin, dan Syuhada' (Al-Tirmidzi, 2002: 99) 
Dengan kata lain mencari rizki adalah termasuk dalam ranah ibadah maka dari itu, dalam mencari rizki harus dengan cara yang baik yaitu dengan kejujuran, tidak ada kecurangan, tidak ada unsur penipuan dan pengkhianatan. Semua prinsip-prinsip ini sudah diterapkan di koperasi BMT UGT Sidogiri, artinya mereka sudah menerapkan prinsip bekerja sebagai manifestasi ibadah kepada Allah SWT.

Setelah menganalisis data di lapangan tentang akad yang digunakan, aktifitas peribadatan para pimpinan dan karyawan serta prinsip-prinsip yang digunakan di koperasi BMT UGT Sidogiri maka dapat ditarik benang merah bahwa aplikasi ayat-ayat bisnis tentang bisnis sebagai ibadah sudah dilakukan dengan baik di koperasi BMT UGT Sidogiri.

\section{Bisnis professional}

Dari data di lapangan diketahui bahwa koperasi BMT UGT Sidogiri merupakan lembaga yang profesional hal ini terlihat dalam praktek bisnisnya yang telah menerapkan prinsip keadilan bagi semua pihak, atau tidak mendhalimi siapapun sebagaimana hasil wawancara dengan ustadz Ismail berikut:

Selain bagi hasil apakah ada uang tambahan yang dibebankan kepada nasabah?

Tidak ada yang penting mereka termasuk anggota koperasi itu saja.Apakah karyawan/ orang dalam juga bisa mengajukan pembiayaan dan apakah syarat untuk orang dalam sama dengan yang lain?

Bisa, semua punya hak yang sama baik karyawan maupun anggota biasa, dan semua persyaratannya juga tidak dibeda-bedakan.

Apakah kerahasiaan nasabah terjamin?

Iya pasti kami akan merahasiakan privacy nasabah terkait dengan tanggungan mereka di koperasi BMT UGT Sidogiri ini.

Bagaimana system pencatatannya apakah menggunakan aplikasi program keuangan standar untuk BMT?

Iya di sini menggunakan system online yang terkoneksi dengan bank yang bekerja sama dengan kita seperti BRI Syari’ah, BNI Syariah dan bank Jatim (Ismail, Wawancara: 2015)

Penerapan prinsip keadilan di BMT UGT Sidogiri telah sejalan dengan konsep bisnis dalam al-Qur'an, yang mana bisnis dipandang professional jika memenuhi dua unsur yaitu 


\section{Aplikasi ayat-ayat bisnis dalam al-Qur'an...(Moh. Toriquddin )}

bisnis harus adil dalam menakar dan menimbang, dan berbuat adil terhadap orang lain. Untuk lebih jelasnya berikut analisis aplikasi bisnis di BMT UGT Sidogiri ditinjau dengan teori bisnis perspektif al-Qur'an melaui dua unsur sebagai berikut:

Pertama, dengan menggunakan teori induksi dari ayat-ayat bisnis di dalam al-Qur'an yang mengindikasikan bahwa dalam menimbang dan menakar harus dengan cara adil sebagai mana surat al-An'am ayat: 152 berikut:

Dan janganlah kamu dekati harta anak yatim, kecuali dengan cara yang lebih bermanfaat, hingga sampai ia dewasa. dan sempurnakanlah takaran dan timbangan dengan adil. Kami tidak memikulkan beban kepada sesorang melainkan sekedar kesanggupannya. dan apabila kamu berkata, Maka hendaklah kamu Berlaku adil, Kendatipun ia adalah kerabat(mu), dan penuhilah janji Allah. yang demikian itu diperintahkan Allah kepadamu agar kamu ingat.

Menurut M. Quraish Shihab bahwa larangan menyangkut harta dimulai dengan larangan mendekati harta kaum lemah, yakni anak-anak yatim. Ini sangat wajar karena mereka tidak dapat melindungi diri dari penganiayaan akibat kelemahannya. Dan karena itu pula, larangan ini tidak sekadar melarang memakan atau menggunakan, tetapi juga mendekati.

Lebih lanjut ia menjelaskan bahwa larangan mendekati harta anak yatim apabila menggunakan cara tidak sah kecuali dengan cara yang terbaik, sehingga dapat menjamin keberadaan, bahkan pengembangan harta itu, dan hendaklah pemeliharaan secara baik itu berlanjut hingga ia (anak yatim itu) mencapai kedewasaannya dan menerima dari kamu harta mereka untuk mereka kelola sendiri (Shihab, 2002: 344).

Sejalan dengan pendapat di atas adalah pendapat Muhammad bin Jarir al-Thabari maksud dari ayat wa là taqrābu māla al-yatim illa bi al-latiy hiya absan/ dan janganlah kamu mendekati harta anak yatim, kecuali dengan cara yang lebih bermanfaat adalah " janganlah kalian mendekati harta anak yatim kecuali untuk kemaslahatannya, dan menghasilkan sesuatu dari harta tersebut (alThabari, 2008: 682).

Sedangkan menyangkut takaran dan timbangan menggunakan kata perintah wa aufü alkaiyla wa al-mizāna bi al-qisț/ dan sempurnakanlab takaran dan timbangan dengan adil. Mereka dituntut untuk memenuhi secara sempurna timbangan dan takaran, sehingga perhatian mereka tidak sekadar pada upaya tidak mengurangi tetapi pada upaya penyempurnaan. Perintah menyempurnakan ini juga mengandung dorongan untuk meningkatkan kemurahan hati dan 
kedermawanaan yang diakui sebagai sifat terpuji, dari pada sekadar berlaku adil bukan justru mengurangi dan mencurinya (Shihab, 2002: 346).

Adapun menurut al-Thabari ayat wa aufü al-kaiyla wa al-mizana bi al-qisth/dan sempurnakanlah takaran dan timbangan dengan adil, maksudnya ialah janganlah kalian mengurangi timbangan ketika kalian menimbang untuk manusia akan tetapi penuhilah hak-hak mereka secara sempurna dengan cara yang adil (Al-Thabari, 2008: 686).

Dalam surat al-Isra' (17): 35 dijelaskan:

Dan sempurnakanlah takaran apabila kamu menakar, dan timbanglah dengan neraca yang benar. Itulah yang lebih utama (bagimu) dan lebih baik akibatnya

Abu Ja'far al-Thabari menjelaskan ayat di atas bahwa Allah menetapkan agar apabila kalian menakar untuk manusia, maka sempurnakanlah hak mereka sebelum kalian, dan janganlah merugikan mereka. Wa żinū bi al-qistäsi al-mustaqim/ dan timbanglab dengan neraca yang benar, maksudnya adalah Allah memerintahkan agar kalian menimbang dengan timbangan yang lurus, yaitu adil, tidak bengkok, tidak berat sebelah, dan tidak ada unsur penipuan (AlThabari, 2008: 672).

Sementara dalam surat al-Syuara' (26): 181-182 dijelaskan:

Sempurnakanlah takaran dan janganlah kamu Termasuk orang- orang yang merugikan, dan timbanglah dengan timbangan yang lurus.

Kata aufu berarti perintah menyempurnakan artinya menjadikan sesuatu sempurna janganlah menjadikan timbangannya berkurang. Kata al-mukhsir adalah yang merugikan dan mengurangi, janganlah kalian termasuk orang-orang yang berbuat curang. Kata al-Qistas adalah timbangan (Ibn Asyur, 2000: 214).

Untuk memenuhi rasa keadilan, koperasi BMT UGT Sidogiri telah menerapkan prinsip keadilan dengan cara tidak mengenakan uang tambahan bagi nasabah, menyamakan hakhak mereka baik nasabah biasa maupun nasabah yang sekaligus menjadi karyawan, dan menjaga kerahasiaan identitas nasabah serta system pencatatan keuangan modern dengan system e-banking. Dengan demikian maka apa yang dilakukan koperasi BMT UGT Sidogiri sudah sesuai dengan pesan-pesan al-Qur'an dengan mempraktekkan ayat-ayat yang menegaskan agar berbuat adil dalam menakar dan menimbang atau dengan kata lain berbuat adil dan tidak mendzalimi siapapun. 
Kedua, dari hasil wawancara ditemukan bahwa di koperesi BMT UGT Sidogiri tidak membeda-bedakan nasabah antara muslim dan non muslim, dan memberi tenggang waktu bagi nasabah yang kesulitan keuangan, dengan kata lain bahwa di koperasi BMT UGT Sidogiri telah diterapkan prinsip keadilan bagi orang lain apapun agamanya dan justru mengedepankan unsur ukhuwah dalam menagih kredit yang macet, sebagaimana data berikut:

Nasabah apakah dibatasi untuk orang Muslim saja?

Sebenarnya tidak, siapa saja boleh menjadi anggota dan nasabah koperasi BMT UGT tetapi kenyataannya mereka yang datang ke sini ya semuanya orang Islam jadi seratus persen anggota dan nasabah kita adalah orang Islam.

Kalau ada kredit macet bagaimana cara mengatasinya?

Ada tim khusus yang bertugas untuk menagih hutang tersebut. Yang dilakukanoleh tim ini biasanya membuat perjanjian/perpanjangan masa pelunasan dan dalam penagihan masih tetap mengedepankan ukhuwah. Jika sampai tiga kali perpanjangan ternyata belum lunas maka jaminan tersebut di lelang oleh pihak Koperasi BMT UGT Sidogiri (Baihaqi, Wawancara: 2015).

Data tersebut dianalisa dengan teori induksi dari ayat-ayat bisnis perspektif al-Qur'an yang mengindikasikan bahwa kita harus berbuat adil terhadap orang lain walaupun terhadap non muslim sekalipun sebagai mana surat al-Nahl (16): 90 berikut:

Sesungguhnya Allah menyuruh (kamu) Berlaku adil dan berbuat kebajikan, memberi kepada kaum kerabat, dan Allah melarang dari perbuatan keji, kemungkaran dan permusuhan. Dia memberi pengajaran kepadamu agar kamu dapat mengambil pelajaran.

Manusia dituntut untuk menegakkan keadilan walau terhadap keluarga, ibu bapak dan dirinya, bahkan terhadap musuh sekalipun. Keadilan yang pertama dituntut adalah dari diri dan terhadap diri sendiri dengan jalan meletakkan syahwat dan amarah sebagai tawanan yang harus mengikuti perintah akal dan agama, bukan menjadikannya tuan yang mengarahkan akal dan tuntunan agamanya. Karena jika demikian, ia tidak berlaku adil, yakni tidak menempatkan sesuatu pada tempatnya yang wajar (Shihab, 2002: 328).

Sedangkan bagaimana cara untuk memperlakukan orang-orang non muslim dijelaskan dalam surat al-Mumtahanah (60): 8: 
Allah tidak melarang kamu untuk berbuat baik dan Berlaku adil terhadap orang-orang yang tiada memerangimu karena agama dan tidak (pula) mengusir kamu dari negerimu. Sesungguhnya Allah menyukai orang-orang yang berlaku adil.

Allah melarang orang Islam berkasih sayang dengan orang-orang musyrik, tetapi mengecualikan orang-orang musyrik yang tidak menyimpan permusuhan kepada orangorang Islam. Ayat ini turun dilatarbelakangi oleh seorang perempuan bernama Qutailah ia adalah ibu dari Asma' binti Abu Bakr. Ketika ia ke Madinah untuk menemui anaknya, Asma' bertanya kepada Nabi apakah aku menyambung tali silaturrahim dengannya? Nabi menjawab: iya sambunglah tali silaturrahim dengan ibumu. Kata Barru adalah memperlakukan dengan baik dan memulyakan. Sedangkan kata qist $\}$ adalah adil, fungsi ila adalah untuk arti seimbang maksudnya perlakukanlah mereka sebagaimana mereka memperlakukan kalian dalam kekerabatan. Ayat ini membolehkan berinteraksi secara baik dengan orang non muslim (Ibn Asyur, 2000: 37).

Allah memerintahkan kepada orang-orang yang beriman untuk selalu menegakkan kebenaran dan menjadi saksi yang adil. Juga melarang kebencian kita kepada seseorang mengakibatkan kita tidak berbuat adil kepada orang tersebut hal ini dijelaskan di dalam surat al-Maidah ayat: 8 :

Hai orang-orang yang beriman hendaklah kamu Jadi orang-orang yang selalu menegakkan (kebenaran) karena Allah, menjadi saksi dengan adil. dan janganlah sekali-kali kebencianmu terhadap sesuatu kaum, mendorong kamu untuk Berlaku tidak adil. Berlaku adillah, karena adil itu lebih dekat kepada takwa. dan bertakwalah kepada Allah, Sesungguhnya Allah Maha mengetahui apa yang kamu kerjakan.

Maksudnya adalah sempurnakanlah nikmat-Ku kepadamu dan jadilah orang-orang yang menegakkan keadilan karena mengharap pahala dari Allah, maka berikanlah hak-hak mereka, dan bersaksilah dengan benar tanpa condong kepada kerabatmu, dan menganggap enteng terhadap musuh kalian. Dan janganlah kalian meninggalkan keadilan dan mengedepankan permusuhan dari kebenaran. Ini merupakan dalil untuk merealisasikan hukum dan persaksian bagi musuh dalam masalah permusuhannya karena Allah bukan karena nafsu kebencian (Al-Qurtubi, 2006: 109).

Dari analisa ini bisa dipahami bahwa kopereasi BMT UGT Sidogiri telah menerapkan prinsip-prinsip keadilan terhadap orang lain dengan tidak membeda-bedakan non muslim 


\section{Aplikasi ayat-ayat bisnis dalam al-Qur'an...(Moh. Toriquddin )}

dengan orang Islam serta memberikan waktu tangguh bagi nasabah yang kesulitan keuangan. Singkatnya koperasi BMT UGT Sidogiri telah menerapkan ayat-ayat bisnis secara baik dalam hal bersikap adil terhadap orang lain.

Setelah menganalisa data di lapangan tentang cara menimbang dan menakar secara adil dan berbuat adil terhadap orang lain yang dilakukan di koperasi BMT UGT Sidogiri maka dapat ditarik benang merah bahwa aplikasi ayat-ayat bisnis tentang bisnis secara professional sudah dilakukan dengan baik di koperasi BMT UGT Sidogiri.

\section{Bisnis beretika}

Data yang diperoleh dari lapangan menunjukkan bahwa dalam memberikan pemahaman bagi nasabah yang ditolak proposalnya dilakukan dengan cara lemah lembut agar tidak menyakiti hati nasabah sebagaimana data berikut:

Apakah ada nasabah yang tidak di setujui permohonannya? Mengapa?

Ada, karena usaha mereka belum jalan satu tahun, atau karena track record-nya kurang baik.

Bagaimana cara menjelaskan nasabah yang ditolak proposalnya?

Dijelaskan dengan bahasa yang sopan dan baik serta lemah lembut, agar mereka bisa menerima keputusan itu (Baihaqi, Wawancara: 2015).

Cara menolak proposal di di BMT UGT Sidogiri telah sejalan dengan konsep bisnis dalam al-Qur'an, yang mana bisnis dianggap beretika jika memenuhi dua unsur yaitu bisnis harus dengan cara lemah lembut dan bersikap sopan santun dalam melayani nasabah. Untuk lebih jelasnya berikut analisis aplikasi bisnis di BMT UGT Sidogiri ditinjau dengan teori bisnis perspektif al-Qur'an melaui dua unsur sebagai berikut:

Pertama dengan menggunakan teori induksi dari ayat-ayat bisnis di dalam al-Qur'an yang mengindikasikan bahwa dalam melayani nasabah harus dengan cara lemah lembut sebagai mana surat al-Anbiya' ayat 107 berikut:

"Dan tiadalah kami mengutus kamu, melainkan untuk (menjadi) rahmat bagi semesta alam"

Menurut al-Alusi kata wa mā arsalnāka aku tidak mengutusmu dengan membawa ajaran dan hukum sebagai tolok ukur kebahagiaan dunia akhirat kecuali disebabkan untuk 
memberikan kasih sayang bagi alam semesta dengan menjelaskan apa yang telah disampaikan Allah kepadamu.

Yang dimaksud dengan alam semesta adalah mencakup orang-orang kafir. Lebih lanjut Alusi menjelaskan bahwa Rasulullah saw. diutus untuk memberikan kasih sayang bagi semua makhluk di alam semesta baik malaikat, manusia, jin, dan tidak ada perbedaan antara mu'min dan kafir dari golongan jin dan manusia (Al-Alusi, 2005: 486).

Dalam rangka mengemban tugas memberi rahmat bagi alam, maka Allah menciptakan Nabi saw. sebagai orang yang penuh kasih sayang seperti yan g dijelaskan dalam surat alTaubah ayat: 128, Ali Imran ayat: 159, sebagai berikut:

Sungguh telah datang kepadamu seorang rasul dari kaummu sendiri, berat terasa olehnya penderitaanmu, sangat menginginkan (keimanan dan keselamatan) bagimu, amat belas kasihan lagi penyayang terhadap orang-orang mukmin.

Rasulullah SAW. membaca ayat laqad jāakum rasūlun min anfusikum, kemudian Ali ra. berkata wahai rasulullah apa arti anfusikum? Rasul menjawab saya adalah orang yang paling luhur di antara kalian dalam segi nasab dan keturunan, tidak ada dari kelompokku dan kelompok orang tuaku dari nabi Adam yang melakukan perzinaan semuanya melakukan pernikahan.

Kata anfus adalah jama' dari kata nafsun yang berarti diri mereka maksudnya dari beberapa nasab mereka atau dari dalam nasab kalian. Kata az̧iz berarti berat dalam jiwa. Kata anittum kesedihan kalian. Sifat nabi disebutkan untuk menunjukkan perilakunya yang penuh dengan kelembutan terhadap umatnya dan mengingatkan mereka agar tidak terjerumus dalam siksa di dunia dan akhirat. Kata harisun adalah sangat menginginkan sesuatu dan mendorongnya. Roūf sangat belas kasih yaitu kelembutan yang timbul ketika terjadi bahaya pada diri orang yang dikasihi dan rabim sangat penyayang (Ibn Asyur, 2000: 416).

Efek dari sikap lemah lembut Rasulullah saw dijelaskan dalam surat Ali Imran (3): 159:

Maka disebabkan rahmat dari Allah-lah kamu berlaku lemah lembut terhadap mereka. sekiranya kamu bersikap keras lagi berhati kasar, tentulah mereka menjauhkan diri dari sekelilingmu. Karena itu ma'afkanlah mereka, mohonkanlah ampun bagi mereka, dan bermusyawaratlah dengan mereka dalam urusan itu. Kemudian apabila kamu telah membulatkan tekad, maka bertawakkallah kepada Allah. Sesungguhnya Allah menyukai orang-orang yang bertawakkal kepada-Nya. 
Menurut al-Thabari dikarenakan belas kasihan dan kasih sayang Allah kepadamu wahai Muhammad, juga kepada orang yang beriman kepadamu dari kalangan para sahabat, sehingga kalian bisa berlaku lembut kepada para pengikutmu dan sahabat-sahabatmu. Dimudahkan bagi mereka bergaul denganmu, sehingga bagus akhlakmu kepada mereka, dan kamu bisa bersabar dalam menghadapi cobaan dari mereka. bahkan kamu bisa memaafkan orang yang berlaku dzalim kepadamu, dan membiarkan banyak orang yang seandainya engkau berlaku kasar kepada mereka, niscaya mereka akan meninggalkanmu, akan tetapi Allah swt. mengasihi mereka dan mengasihimu. Jadi dengan rahmat Allahlah engkau bisa berlaku lembut kepada mereka (Al-Thabari, 2008: 122).

Kedua, data di lapangan menunjukkan bahwa pelayanan nasabah di koperasi BMT UGT Sidogiri dilakukan dengan cara sopan santun sebagai berikut:

Berdasarkan pengamatan peneliti di lokasi penelitian bahwa ketika ada tamu mereka mengucapkan salam terlebih dahulu, lalu menannyakan keperluan tamu, jika masih ada nasabah lain maka tamu di persilahlan duduk di sofa ruang tunggu yang cukup nyaman karena di samping bersih, full ac, juga ada beberapa majalah dan koran serta air minum kemasan. Dari segi penampilan seluruh karyawan menggunakan kopyah dan seragam baju koko putih dan sarung hijau, sungguh mencitrakan santri tulen yang penuh sopan santun dan professional (Observasi, Sidogiri: 2015).

Dengan menggunakan teori induksi dari ayat-ayat bisnis di dalam al-Qur'an yang mengindikasikan bahwa dalam melayani nasabah harus dengan cara sopan santun sebagai mana dalam surat al-Hijr ayat 88 berikut:

Janganlah sekali-kali kamu menunjukkan pandanganmu kepada kenikmatan hidup yang telah Kami berikan kepada beberapa golongan di antara mereka (orang-orang kafir itu), dan janganlah kamu bersedih hati terhadap mereka dan berendah dirilah kamu terhadap orang-orang yang beriman.

Kata la tamuddanna 'ainayka artinya janganlah berharap dengan pandanganmu dan janganlah selalu memandang pada kenikmatan dunia dari kelompok orang-orang yahudi, nasrani, dan orang-orang musyrik. Kata la tahzan alaybim adalah janganlah engkau bersedih memikirkan mereka karena mereka tidak beriman. Kata wahfid janāhakka li al-mu'minīn, merupakan sindiran untuk berbuat lemah lembut terhadap orang mukmin (Al-Alusi, 2005: 69). 
Larangan bersikap sombong dijelaskan dalam surat Luqman (31): 18-19:

Dan janganlah kamu memalingkan mukamu dari manusia (karena sombong) dan janganlah kamu berjalan di muka bumi dengan angkuh. Sesungguhnya Allah tidak menyukai orang-orang yang sombong lagi membanggakan diri. Dan sederhanalah kamu dalam berjalan dan lunakkanlah suaramu. Sesungguhnya seburuk-buruk suara ialah suara keledai.

M. Quraish Shihab menjelaskan janganlah engkau berkeras memalingkan pipimu yakni mukamu dari manusia -sipapun dia- didorong oleh penghinaan dan kesombongan. Tetapi tampillah kepada setiap orang dengan wajah berseri penuh rendah hati. Dan bila engkau melangkah, janganlah berjalan di muka bumi dengan angkuh, tetapi berjalanlah dengan lemah lembut penuh wibawa. Sesungguhnya Allah tidak menyukai yakni tidak melimpahkan anugerah kasih saying-Nya kepada orang-orang yang sombong lagi membanggakan diri. Dan bersikap sederhanalah dalam berjalan, yakni jangan membusungkan dada dan jangan juga merunduk bagaikan orang sakit. Jangan lari tergesa-gesa dan jangan juga sangat perlahan menghabiskan waktu. Dan lunakkanlah suaramu sehingga tidak terdengar kasar bagaikan teriakan keledai. Sesungguhnya seburuk-buruk suara adalah suara keledai (Shihab, 2000: 139).

Dan janganlah kamu serahkan kepada orang-orang yang belum sempurna akalnya harta (mereka yang ada dalam kekuasaanmu) yang dijadikan Allah sebagai pokok kehidupan. berilah mereka belanja dan pakaian (dari hasil harta itu) dan ucapkanlah kepada mereka kata-kata yang baik (al-Nisā' (4): 5).

Yang dimaksud dengan orang-orang yang belum sempurna akalnya adalah berlaku umum, baik anak kecil maupun orang dewasa, laki-laki maupun perempuan. Safīh (orang yang belum sempurna akalnya), wali tidak boleh memberikan hartanya, mereka adalah orang yang dibatasi (transaksinya), karena ia akan menyia-nyiakan, menghambur-hamburkan, merusak, serta mengelola hartanya dengan buruk (al-Thabari, 2008: 434).

Kata wa qülü lahum qaulan ma'rüfan adalah ucapkanlah wahai wali orang-orang yang belum sempurna akalnya perkataan yang baik, seperti jika kalian telah mengerti dan mendapat petunjuk, maka kami akan menyerahkan harta kalian dan kami akan membukakan jalan untuk mengambil harta kalian itu (al-Thabari, 2008: 447). 


\section{Aplikasi ayat-ayat bisnis dalam al-Qur'an...(Moh. Toriquddin )}

Setelah menganalisa data di lapangan tentang cara menolak nasabah dengan lemah lembut dan melayaninya dengan sopan santun yang dilakukan di koperasi BMT UGT Sidogiri maka dapat ditarik benang merah bahwa aplikasi ayat-ayat bisnis tentang bisnis beretika sudah dilakukan dengan baik di koperasi BMT UGT Sidogiri.

\section{Tujuan pendirian BMT UGT Sidogiri}

Untuk menjawab rumusan masalah ke dua tentang tujuan pendirian koperasi BMT UGT Sidogiri maka ditemukan jawaban dari wawancara antara Syaiful Bakhri penulis buku "Sukses Koperasi Syariab” dengan Ustadz. Mahmud Ali Zain sebagai berikut:

Apa tujuan mendirikan koperasi BMT UGT sidogiri?

Tujuan didirikan BMT adalah berawal dari keprihatinan terhadap ekonomi umat, dan tidak berjalannya ekonomi syariah. Di sisi lain keprihatinan tercekiknya kaum lemah (dhuafa') dan kaum yang tertindas (mustad'afin). Keberadaan BMT diharapkan sebagai sumbangsih pesantren dalam mengembangkan ekonomi umat. Yaitu merealisasikan ayat wa ta'awanu 'alal birri wattaqwa yaitu tolong menolong lewat ekonomi umat, dan agar harta tidak hanya berputar pada segelintir orang-orang kaya saja (Bakhri, 2005: 11).

Dengan kata lain bahwa latar belakang berdirinya koperasi BMT UGT Sidogiri adalah keprihatinan terhadap maraknya praktek rentenir di masyarakat dan belum berlakunya system keuangan syari'ah secara maksimal. Data ini dianalisis dengan menggunakan teori induksi dari ayat-ayat bisnis di dalam al-Qur'an yang mengindikasikan bahwa dalam mencari rezeki harus meninggalkan praktek riba sebagaimana dijelaskan dalam surat al-Nisa': 29, Ali Imran: 130 dan al-Baqarah: 278:

Hai orang-orang yang beriman, janganlah kamu saling memakan harta sesamamu dengan jalan yang batil, kecuali dengan jalan perniagaan yang Berlaku dengan suka sama-suka di antara kamu. dan janganlah kamu membunuh dirimu. Sesungguhnya Allah adalah Maha Penyayang kepadamu.

M. Quraish Shihab menafsirkan kata bil bătil, memakan harta dengan tidak seimbang, sedang perolehan interaksi yang tidak seimbang itulah yang dimaksud dengan batil. Janganlah kamu memakan harta sebagian antara kamu, yakni janganlah memperoleh dan menggunakannya. Perolehan yang tidak seimbang adalah batil dan yang batil adalah segala sesuatu yang tidak hak, tidak dibenarkan oleh hukum, serta tidak sejalan dengan tuntutan 
ilahi, walaupun dilakukan atas dasar kerelaan yang berinteraksi (Shihab, 2002: 57). Selanjutnya larangan memakan harta dari hasil riba dijelaskan dalam surat Ali Imran (3): 130. berikut:

Hai orang-orang yang beriman, janganlah kamu memakan riba dengan berlipat ganda dan bertakwalah kamu kepada Allah supaya kamu mendapat keberuntungan.

Menurut M. Quraish Shihab kata ad'äfan mudäa afah bukanlah syarat bagi larangan ini, tetapi sekadar menggambarkan kenyataan yang berlaku ketika itu. Betapapun utang piutang harus berlandaskan rasa suka sama suka (Shihab, 2002: 73). Dalam surat al-Baqarah: 278 Allah secara tegas memerintahkan untuk meninggalkan riba, sebagai berikut:

Hai orang-orang yang beriman, bertakwalah kepada Allah dan tinggalkan sisa Riba (yang belum dipungut) jika kamu orang-orang yang beriman.

Setelah menganalisa tujuan pendirian koperasi BMT UGT Sidogiri dengan menggunakan teori induksi dari ayat-ayat bisnis di dalam al-Qur'an yang mengindikasikan bahwa dalam mencari rezeki harus meninggalkan praktek riba, maka bisa dipahami bahwa di koperasi BMT UGT Sidogiri telah menerapkan ayat-ayat bisnis tentang perintah meninggalkan praktek riba dengan baik.

\section{Penutup}

Berdasarkan paparan dan analisis data yang diuraikan sebelumnya dapat disimpulkan sebagai berikut: Pertama, Aplikasi ayat-ayat bisnis tentang bisnis sebagai ibadah, bisnis professional dan bisnis beretika di koperasi BMT UGT Sidogiri telah dipraktekkan dengan baik. Bisnis sebagai ibadah ditandai dengan akad yang digunakan adalah akad syar'i, aktifitas bisnis tidak melupakan untuk beribadah kepada Allah dengan selalu shalat dhuha, shalat dhuhur dan asar secara berjamaah ketika adzan berkumandang, dan penggunaan prinsip kejujuran (shiddiq), komunikatif (tabligh), amanah (dapat dipercaya), fathonah (profesional) dalam menjalankan bisnis sebagai manifestasi ibadah kepada Allah. Kedua, Bisnis profesional ditandai dengan penerapan prinsip keadilan dengan cara tidak mengenakan uang tambahan bagi nasabah, menyamakan hak-hak mereka baik nasabah biasa maupun nasabah yang sekaligus menjadi karyawan, dan menjaga kerahasiaan identitas nasabah serta system pencatatan keuangan modern dengan system e-banking. Ketiga, Bisnis beretika ditandai dengan penolakan terhadap nasabah dengan lemah lembut dan melayaninya dengan sopan santun. Adapun alasan pendirian 
koperasi BMT UGT Sidogiri adalah merupakan keprihatinan terhadap maraknya praktek bisnis riba dan kurang berlakunya bisnis syar'i secara maksimal.

\section{Daftar pustaka}

Alusi al-,Shihab al-Din Mahmud bin Abd. Allah al-Husaini Rüh al-Ma'anifi Tafsìr al-Qur'an alAžìm wa al-Sab’i al-Mathāni, Juz.12. Kairo: Dār al-Hadits, 2005.

Munawwar al-, Said Agil Husin Aktualisasi Nilai-Nilai Qur'ani, Jakarta: Kalam Media, 2000. Qurthubi al-, Syamsuddin. Tafsir al-Qurțbiy, Juz, 6. Beirut: Muassasat al-Risālah: 2006.

Razi al-, Fakhruddin Mafätīh al-Ghaiyb, Juz 11. Beirut: Dār Ihyā’ al-Turāts al-Arabiy, 2001.

Suyuti al-, Al-Jamī' al-Saghïr, juz.2. Makkah al-Mukarramah: Maktabah Nazār Musthofa alBàz, 2000.

Thabari al-, Muhammad bin Jarir. Tafsìr al-Ṭabari, Juz. 13. Beirut: Dār al-Kutub al-'Ilmiyah, 2005.

Thabari al-, Abu Ja'far Muhammad bin Jarir. Tafsir al-Ṭabari, Terj. Akhmad Affandi dkk, Juz.10, Jakarta: Pustaka Azzam, 2008.

Tirmidzi al-, Muhammad bin Isa bin Surah bin Musa bin Dhakhak. Sunan al-Tirmidhi, juz.5 Beirut: Maktabah al-Ma’arif, 2002.

Arifin, Imron. Kepemimpinan Kyai (Kasus Pondok Pesantren Tebuireng), Malang: Kalima Shahada Press, 1993.

Azra, Azyumardi. Pendidikan Islam, Tradisi dan Modernisasi Menuju Millenium Baru, Jakarta: Logos Wacana Ilmu, 1999.

Baihaqi, Wawancara, Sidogiri, 11 Agustus 2015

Bakhri, Mokh. Syaiful Sukses Koperasi Syariah Di Sidogiri The Best Islamic Micro Finance, Pasuruan: Penerbit Cipta Pustaka Utama, 2015.

Bawani, Imam. Pesantren Anak-anak Sidayu Gresik Jawa Timur, Studi Tentang Sistem Pendidikan dan Perkembangannya, Disertasi Doktor, Yogyakarta: Pascasarjana IAIN Sunan Kalijaga Yogyakarta, 1995.

Brosur Produk Simpanan Koperasi Simpan Pinjam Syariah BMT UGT Sidogiri

Bruinessen, Martin Van. Kitab Kuning, Pesantren dan Tarekat, Bandung: Mizan, 1995.

Bogdan, Robert \& J Taylor, Stevan. Introduction to Qualitative Methods Research, A Phenomenological Approach to Social Sciences. New York: John Willey \& Son, 1975.

Dhofier, Zamakhsyari. Tradisi Pesantren: Studi tentang Pandangan Hidup Kiai, Jakarta: LP3ES, 1982. 
Faishol, Amir. abstrak Disertasi "Tradisi Keilmuan Pesantren, (Studi Banding Antara Nurul Iman dan Assalam), Yogyakarta: Pascasarjana, 2001.

Ghazali, M. Bahri. Pengembangan Lingkungan Hidup dalam Masyarakat, Kasus Pondok Pesantren an-Nuqayah dalam Menumbubkan Kesadaran Lingkungan Hidup, Disertasi Doktor, Yogyakarta: Pascasarjana IAIN Sunan Kalijaga Yogyakarta, 1995.

Ibn. Asyur, Muhammad Thahir Al-Tabrir wa al-Tanwir, Juz. 10, Beirut: Muassasah al-Tárich, 2000.

Ibn Hambal, Abu Abd. Allah Ahmad bin Muhammad. Musnad Ahmad, juz.37. Kairo: Dār al-Hadits, 1995.

Ibn. Hayyan Muhammad bin Yususf bin Ali bin Yusuf bin Hayyan, Tafsir Bahru al-Mukit, Juz. 8. Beirut: Dār al-Kutub al-Ilmiyah, 2007.

Ismail, Wawancara, Sidogiri, 11 Agustus 2015

Lajnah Pentashihan Mushaf al-Qur'an Balitbang dan Diklat Kemenag RI, Tafsir al-Qur'an Tematik Pembangunan Ekonomi Umat, Jakarta: Penerbit Aku Bisa, 2012.

Adam, L. Method and Forms of Infestigation and Recording of Native Customary Law in The Netherlands East Indies before the War. Oxford: Oxford University Press, 1952.

Mas'ud, Abdurrahman. Intelektual Pesantren (Perhelatan Agama dan Tradisi), Yogyakarta: LKiS, 2004.

Mas'ud, Abdurrahman. Reformasi Pendidikan Agama Menuju Masyarakat Madani, dalam Ismail SM dan Abdul Mukti (ed), Pendidikan Islam, Demokratisasi dan Masyarakat Madani, Yogyakarta: Pustaka Pelajar, 2000.

Nawawi, Hadari. Metode Penelitian Bidang Sosial. Yogyakarta: Gajah Mada University Press, 2007.

Qamar, Mujamil. Pesantren dari Transformasi Metodologi Menuju Demokratisasi Institusi, Jakarta: Erlangga, 2007.

Raharjo, M. Dawam. Pesantren dan Pembaharuan, Jakarta: LP3ES, 1988.

Shihab, M. Quraish. Secercah Cahaya Ilahi Hidup Bersama Al-Qur'an, Bandung: Penerbit Mizan, 2000.

Shihab, M. Quraish. Tafsir al-Misbah, juz.14. Jakarta: Lentera Hati, 2002.

SM, Ismail. Dinamika Pesantren dan Madrasah, Yogyakarta: Pustaka Pelajar, 2002. 